should be in reasonably good or repairable order. Those who are prepared to give or lend apparatus to schools should send a list of what is available to the General Secretary, Association for Science Education, 52 Bateman Street, Cambridge, and should specify what arrangements could be made for its direct handing-over or delivery to those schools which might apply to the Association for it as a result of subsequent publicity".

\section{The Environmental Group}

THE inaugural meeting of the Environmental Group will be held at the Imperial College of Scionce and Technology on December 4. The Group has been formed to provide a forum for the discussion of generalized environmental problems. The discussions and meetings of the group are intended to disseminate information, to assist in providing 'feed-back' of information and to promote more fruitful co-operation between the various professions. Membership of the Environmental Group will be open to all those professionally interested in the environment created by buildings. The members of the provisional committee are: Chairman, P. Burberry; Deputy Chairman, J. S. McCulloch; Secretary, P. A. Jay; Members, A. Aldersey-Williams, A. Benjamin, T. A. Markus, D. Moizer, D. Poole. Further information can be obtained from Peter Jay, 16 Gloucester Place, London, W.1.

\section{The Classification Society}

AT a meoting on April 17, 1964, a new society, the Classification Society, was founded, the aims of which are to promote co-operation and interchange of views betwoen those intorested in the principles and practice of classification in a wide range of disciplines. In order to carry out these aims it is proposed to produce a bulletin contrining references to (and, if possible, summaries of) publications of interest to members, and to arrange meetings. The foundation of the Society follows the holding of a symposium, organized by 'Aslib' on April 6, 1962, entitled "Classification: an Inter-disciplinary Problem", at which it became clear that there are many aspects of classification common to such widely separated disciplines as biology, librarianship, soil science and anthropology, and that opportunities for joint discussion of these aspects would be of value to all the disciplines concerned. Copies of the report of the symposium (price 5s.) can be obtained from Aslib, 3 Belgrave Square, London, S.W.1. The annual subscription to the Society is $£ 1$, entitling members to receive the Bulletin free of charge and to attend and vote at meetings. Further particulars, and a membership application form, can be obtained from the secretary-treasurer, Mr. J. S. I. Gilmour, University Botanic Garden, Cambridge.

\section{Geological Survey of Great Britain and the Museum of Practical Geology}

THE summary of progress of the Geological Survey of Great Britain and the Museum of Practical Geology for 1963 reports that an area of 1,091 square miles of field survey on the 6 -in. scale was completed during the year (Pp. iii +99. London: H.M.S.O., 1964. 6s. 6d. net). Details are given of the many research activities, in field and laboratory, and of the practical application of the results to many economic and industrial problems. Preliminary research on the geochemistry of British shales shows that many of these rocks have an unusually high natural radioactivity. Since 1955 the Survey has carried out aeromagnetic surveys to investigate changes in the strength of the Earth's magnetic field; the results have provided much information concerning concealed geological structures. A new sories of the very useful Water Supply Reports is being published to include recent research and records of underground water. Much revision work has been carried out in the Museum, and attendance at lectures and demonstrations reached a total of 15,665 .

\section{Institution of Civil Engineers}

IN his presidential address to the Institution of Civil Engineers on November 3, Mr. R. M. Wynne-Edwards was critical of the Trend Committee's proposals regarding the Department of Scientific and Industrial Research. He thought that the present independence of the Building. Research Station and the Road Research Laboratory was an important factor in their value to the community, and that it would be a grave error to transfer them to executive ministries-a view which also found expression in the last report of the Road Research Laboratory. Mr. Wynne-Edwards also stressed the importance of determining the most effective way in which the Institution could make its views known to the Government, and expressed. the opinion that one of the most urgent needs was to make full use of British civil engineering knowledge in the underdeveloped countries. To his knowledge, the Department of Technical Co-operation had never yet asked the Institution for its views on any subject. He also instanced the imaginative civil engineering schemes for Morecambe Bay and the Solway as examples of schemes which might fail, not on their merit but for lack of public support, because the community which had to provide the money was insufficiently informed. This demonstrated the need for the Institution to encourage independent thought in these and other topical matters and to find effective means of making them known. There was no room for petty-mindedness or rivalries and he regarded the federation of 13 major professional institutions in the Engineering Institution's Joint Council as a major step towards working together and thinking, speaking and acting as a united profession. Further, the productivity of the construction industries was an immediate challenge to the profession as well as to industry, for in this expenditure and its expansion the engineer and the architect held key positions and were the essential creative force. Whatever reasons might exist for divisions in the construction industry, the profession had a common task in producing the best possible design. He suggested that the engineering content in the construction of a building increased proportionately as its design was adapted to the spccial needs of its users.

\section{Financial and Management Accounting}

United Steel Co., LTd., has published a lucid account of its financial and management accounting practices. The role of financial accounts in providing a record of the transactions of a business and as a means of conforming to statutory requirements is well presented, but the particular appeal of the booklet lies in the way financial accounts are used as the basis of management accounting in the Company. Current transactions are analysed and compared either with past performance or with pre. determined estimates of current performance, in order to provide management with an instrument for the control of efficiency and for future planning. Costing, budgetary control and similar applications of accounting data for the control of industrial activities are well described. Tho publication would be of considerable use to all accountants who fail to use the information they produce for control purposes and invaluablo to all managerial staffs who need to have more than a nodding acquaintance with financial and managemont accounting; no clearer presentation of this difficult subject has been made. Copies can be obtained, free of charge, from the Secretary, United Steel Co., Ltd., Shoffiold.

\section{Radioisotopes, Labelled Compounds and Radiation Sources}

THE recent edition of the catalogue of radioactive products, issued by the Radiochemical Centre, Amersham, is of greatly enlarged size and scope (Catalogue of Radioactive Products: Radioisotopes-Labelled CompoundsRadiation Sources. Pp. $164+13$ plates. Amersham: The 